\title{
Role of hydrological factors in shaping water chemistry of small flow-through Polish lake
}

\author{
Beata Ferencz ${ }^{1}$
}

Received: 2 November 2015/ Accepted: 30 May 2016/Published online: 8 June 2016

(c) The Author(s) 2016. This article is published with open access at Springerlink.com

\begin{abstract}
In this study, allometric relations between all parts of lake-catchment systems have been investigated. Inflow and outflow discharges were the main hydrological factors of terrestrial part of the system. Lake water chemistry was presented not simply as ion concentration, but as ion mass accumulated in the lake basin, taking into account the volume of water stored in the lake basin at that time. Redundancy analysis was used to determine the most significant relations between hydrometeorological factors and lake water chemistry. Power of scaling was calculated afterward. The obtained results showed the strongest relations between the following: inflow 2 (I2) and total phosphorus (TP), outflow and magnesium $\left(\mathrm{Mg}^{2+}\right)$ and chlorides $\left(\mathrm{Cl}^{-}\right)$, flushing time (Tf) and phosphate $\left(\mathrm{PO}_{4}{ }^{3-}\right)$, as well as precipitation $(\mathrm{P})$ and calcium $\left(\mathrm{Ca}^{2+}\right)$-inverse relation. In most cases, negative allometry was observed. The most stable allometric relations occurred between I 2 and TP, the least stable between $\mathrm{Tf}$ and $\mathrm{PO}_{4}{ }^{3-}$. Negative allometry proved a dominant role of hydrological conditions in shaping lake water chemistry. The inverse relationship between $\mathrm{P}$ and $\mathrm{Ca}^{2+}$ resulted from the fact that $\mathrm{Ca}^{2+}$ originated from Cretaceous sediments weathering, not atmospheric input.
\end{abstract}

Keywords Lake-catchment system - Flow-through lake · Allometry $\cdot$ Water chemistry $\cdot$ Nutrients

Beata Ferencz

beata.ferencz@up.lublin.pl

1 Department of Landscape Ecology and Nature Conservation, University of Life Sciences, Akademicka 13, 22-950 Lublin, Poland

\section{Introduction}

Lake-catchment systems are two-dimensional and are composed of terrestrial and aquatic part. Hydrochemical dynamic of a lake catchment area makes up an external load, shaping the direction and intensity of ionic translocation. These processes are consubstantial and affect each other. The power of connections between individual parts of lake-catchment systems subject to the scaling laws and may be presented with allometric theory. For the first time in Polish floodplain lakes, allometry has been used to determine an influence of fluvial impulse on the morphometry of floodplain lakes (Ferencz and Dawidek 2015). Biogens are the most important ions in shaping lakes ecological state (the cause of progressive eutrophication) (Sheffer 1998; Klein and Koelmans 2011). However, hydrological dynamic of a catchment is a driving force of in-lake processes, e.g., flushing time, the degree and rate of ionic transformation (Müller et al. 1998; Lee et al. 2009; Liu et al. 2011). Surface tributaries transport the loads of domestic sewage and agricultural practices shaping the quality of water in a large scale (Ravinda et al. 2003).

Under natural conditions, water quality in small catchment scale is shaped by rocks' susceptibility to the degradation and the time of interaction between water and the host rock (Yidana et al. 2012). Mineral weathering processes determine hydrochemistry of both surface and groundwater in the catchment (Coetsiers and Waltravens 2006; BanoengYakubo et al. 2009). It has been the subject of most hydrochemical analysis in the literature (e.g., Apambire et al. 1997; Abu-Jaber 2001; Wen et al. 2005; Cloutier et al. 2008). Where the residence time is high, the interaction between the rocks and water endures for a long time, leading to a greater degree of interaction that leaches ions into groundwater. Thus, the final quality of the lake water results from the 
dissolution of minerals and ion transport to the lake basin, which is its local drainage area. Catchment part represents a dynamic, complex, and long-term process of accumulation of substrates (rock-forming minerals) and then their dissolution and transport to the border of terrestrial part of the system (lakeshore). The value of the ionic load retained in the lake basin is a derivative of the processes of each component of the lake catchment, and the power of this relationship may be presented allometrically.

The proposed study is based on the estimation of allometric relations between different parts of lake-catchment systems. It is a novel approach to the concept of allometry, which is known in the literature. Allometry focuses on the relationship between the selected values characterizing the system. This relationship is also called scaling law. Generally, scaling laws determine how certain measurable properties of the system change, for example, with its linear size (scale). Allometry in the traditional sense-fundamental concept of allometry (the study of size and its consequences)_examines the relationship between the size and shape of organisms and enables to quantify the changes in proportions.

The proposed approach to the research on lake-catchment systems involves a holistic analysis of the processes shaping the water quality, including terrestrial lake catchment area, lake basin, as well as lake outlet. It is known that interactions of bedrock geology, climate, and hydrology influence both groundwater and surface water of the catchment. The aim of the study was to estimate which environmental factor influences which chemical parameter, taking into account both temporal and spatial variability. It is essential in sustainable water management practices.

\section{Study area}

Lake Chuteckie (vel Słone) belongs to the so-called ŁęcznaWłodawa Lakes, a group of over 70 water bodies, located to the south of the last glaciation boundary. Łęczna-Włodawa Lakes are characterized by small areas and volume of lake basins (the highest Uściwierz's area amounts to 248 ha, the deepest Lake Piaseczno-38 m). Lake Chuteckie is a small water body (lake area, $2.81 \mathrm{ha}$; volume, 124,370 $\mathrm{m}^{3}$; maximum depth, $8.1 \mathrm{~m}$ ) located in the Lublin Upland (Fig. 1). The lake is supplied with two tributaries and drained to the South. The lake basin is surrounded by peat bogs, which are used extensively as pastures.

\section{Methods}

\section{Hydrometeorological measurements}

All the field measurements were carried out from April 2009 to October 2010. Regular readings of lake and stream water stages from electronic staff gauges were done everyday at 7 a.m. According to Smidth (2002) and Pappenberger et al. (2006), the errors of water level measurements are very small $(1-2 \mathrm{~cm})$. Flow rate measurements were taken once a month using Nautilus 2000 or Velaport 801 electromagnetic flow meters. The current meters have a measuring range of $2.5 \mathrm{~m} \mathrm{~s}^{-1}$ and zero with an error of $\pm 2 \mathrm{~mm} \mathrm{~s}^{-1}$. The degree of error amounts to $1 \%$ of the range. Flow sensors were calibrated according to the recommended specifications of the manufacturers. Daily discharges of lake inflows and outflows were determined from a rating curve of each cross section. FRIEND procedure (Flow Regimes from International Experimental and Network Data) was used for a hydrograph division (to surface and underground inflow and outflow).

The algorithm was prepared by the Institute of Hydrology, Wallingford (United Kingdom), as part of the international cooperation International Hydrological Program (IHP) UNESCO. The calculating procedure was based on the construction of pentads periods, in which the minimum values of flow had to fulfill the $\mathrm{Qmin}_{i-1}>0.9 \mathrm{Qmin}_{i}>$ $\mathrm{Qmin}_{i+1}$ condition. The points selected this way created a line that reflected the underground flow (base flow). Daily underground flow ratio was obtained. An algorithm used in this study reflected dynamics of the underground water outflow, especially during the periods of increasing water levels. Groundwater inflow 1 (GI1) has been obtained due to a hydrograph of inflow 1 division, while groundwater inflow 2 (GI2) resulted from a division of a hydrograph of inflow 2 .

The flushing time was calculated using the equation:

$\mathrm{Tf}=Q \times V^{-1}$

where Tf flushing time, $Q$ daily underground outlet, $V$ daily lake volume.

Daily sums of precipitation were calculated using Hellman pluviometer with reception surface $200 \mathrm{~cm}^{2}$. Measurements were taken once a day, at 7.00 UTC. Using Sonel echo-sounder and GPS Garmin receiver, bathymetric measurements were performed once a season. Points were then imported into ArcView software and then plotted on calibrated topographic maps 1:10,000. IDW interpolation method was performed in order to draw bathymetric sketches. Weekly volume of lake basin was calculated on the basis of bathymetric maps.

\section{Chemical methods}

Water samples of inlets, lake, and outlet $(n=96)$ for chemical analysis were collected bimonthly. Using LF300 Fotometer, concentration of $\mathrm{Ca}^{2+}, \mathrm{Mg}^{2+}, \mathrm{HCO}_{3}{ }^{-}, \mathrm{SO}_{4}{ }^{2-}$, $\mathrm{Cl}^{-}, \mathrm{TP}, \mathrm{PO}_{4}{ }^{3-}, \mathrm{TN}, \mathrm{NH}_{4}{ }^{+}, \mathrm{NO}_{3}{ }^{-}, \mathrm{NO}_{2}{ }^{-}, \mathrm{SO}_{4}{ }^{2-}$, and total 


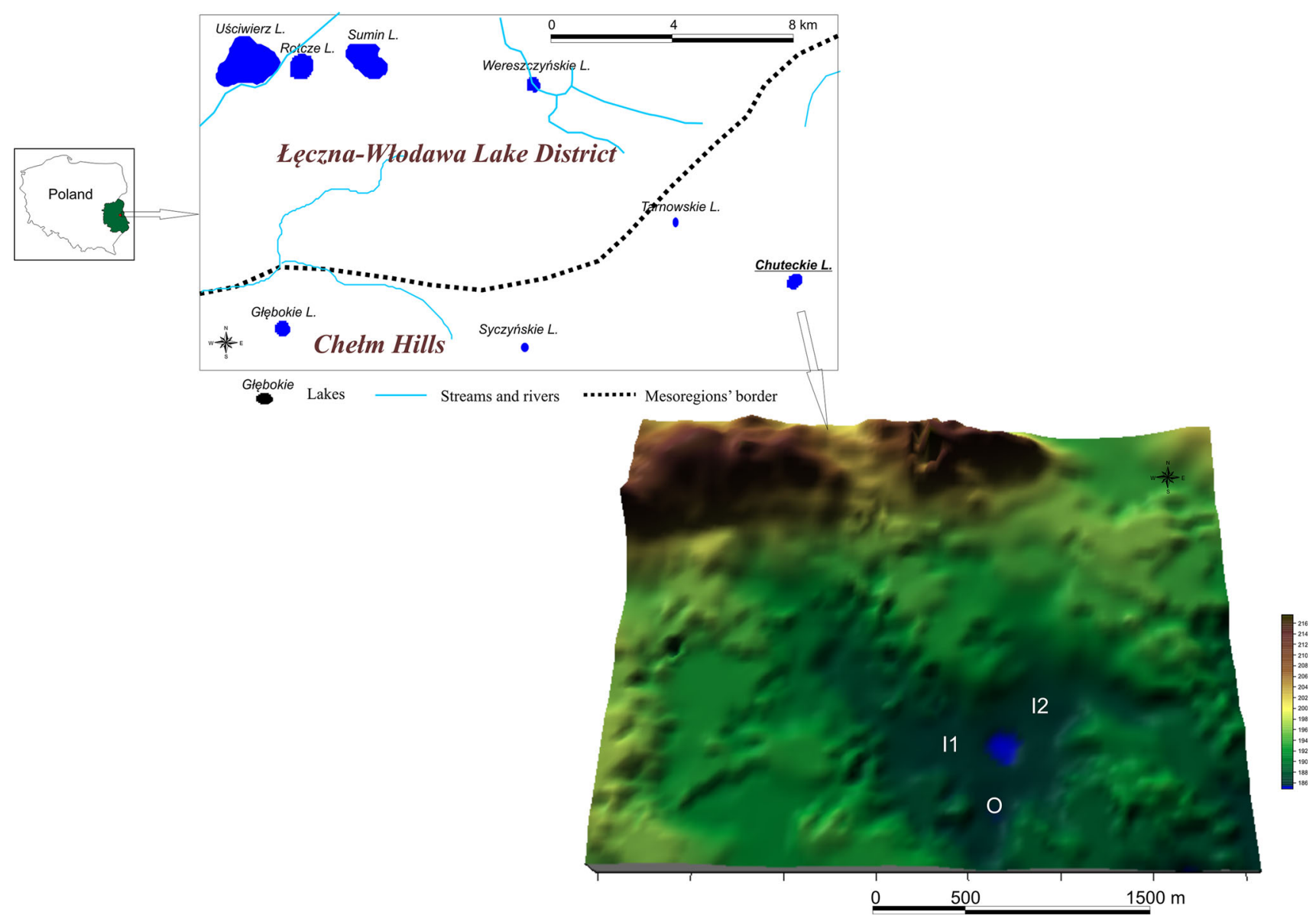

Fig. 1 Location of the lake-catchment system under study

hardness was measured. Measurements were taken in situ in the deepest part of the Lake Chuteckie. Taking into account the volume of water stored in the lake basin at the day of sampling, the temporary ionic concentrations ( $\mathrm{mg}$ $\mathrm{L}^{-1}$ ) were converted to total mass $(\mathrm{kg})$ of particular ion accumulated in the lake basin.

The ionic load of the streams was calculated as follows:

$$
L=C Q
$$

where $L$ load ( $\mathrm{kg}$ year), $C$ ion concentration $\left(\mathrm{mg} \mathrm{dm}^{-3}\right)$, $Q$ discharge $\left(\mathrm{dm}^{3} \mathrm{~s}^{-1}\right)$.

A mass balance of the lake $\left(L_{\mathrm{L}}\right)$ was calculated as a difference between the load entering and those that exits the lake basin (Eq. 3)

$L_{\mathrm{L}}=(\mathrm{LI} 1+\mathrm{LI} 2)-\mathrm{LO}$

where LI1, ionic load transported by the first inflow; LI2, ionic load transported by the second inflow; LO, ionic load transported by the outflow.

\section{Statistical analysis}

Ordination techniques were used to demonstrate relationships between hydrological variables: total inflow 1 (I1), inflow 2 (I2), outflow (O), groundwater inflow 1 (GI1), groundwater inflow 2 (GI2), flushing time (Tf), and the chemical ones. An indirect multivariate detrended correspondence analysis DCA method was used to calculate gradient indicated by chemical variables. The length of the gradient was $<3$ standard deviation; thus, RDA analysis was used to find the strongest relations among hydrometeorological and chemical data. Automatic forward selection of hydrometeorological variables, Monte Carlo permutation test were performed (999 permutations) to determine the most important variables (significance must have exceeded 0.05).

Allometric relations of the highest correlated variables have been quantified using Eq. 4 .

$Y=a X^{b}$ 
The function is the basis of the concept of hydraulic geometry (Bull 1975; Park 1978) and has been widely used in geomorphological literature (Hood 2007; Evans 2012).

An exponent value is crucial from the point of view of allometric analysis, the sign and magnitude of which reflect the rate of change of a dependent variable $Y$ in relation to changes in the independent variable $X$. After the transformation of Eq. 4, the exponent $b$ will be calculated as follows:

$b=\frac{\left(\ln Y_{2}-\ln Y_{1}\right)}{\left(\ln X_{2}-\ln X_{1}\right)}$,

where $X_{1}, X_{2}, Y_{1}$, and $Y_{2}$ are system variables of the two time steps.

This equation, assuming a constant $b$ value, expresses the relation of the dependent variable change with respect to a fixed rate of change of the independent variable. If $0<b<1$, the independent variable $X$ has more significant changes than the dependent variable $Y$. If $b>1$, the dependent variable is characterized by more rapid changes than the independent variable $X$. Accordingly, the first case of this relationship is defined as negative allometry and the second as a positive one (Bull 1975). If $b=1$, the rate of changes of both independent and dependent variables is the same, and allometry is defined as isometric. The exponent sign "+" indicates a directly proportional relation of the variables (convexity of the function), and "-" indicates a relation of inverse proportion (concavity of the function).

\section{Results}

Precipitation showed distinct variability in both years under study. In nine observed months of 2009, almost equal quantity of precipitation occurred than in 12 months of 2010. Very high sums of precipitation (higher than $60 \mathrm{~mm}$ ) were observed from May to August 2009 (Fig. 2).

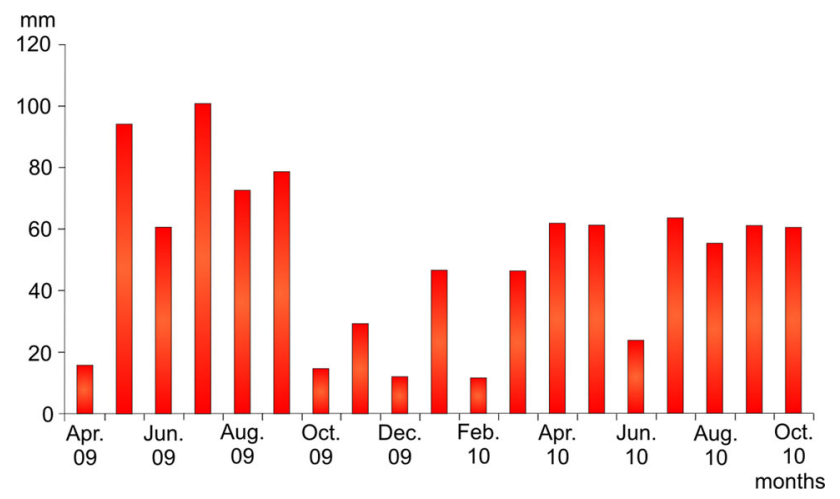

Fig. 2 Distribution of precipitation during the study period
Concentrations of major ions $\left(\mathrm{Ca}^{2+}, \mathrm{HCO}_{3}{ }^{-}, \mathrm{Mg}^{2+}\right.$, $\mathrm{Cl}^{-}, \mathrm{SO}_{4}{ }^{2-}$ ) showed very similar fluctuations in waters of both tributaries. Calcium showed the highest inter-annual stability. The lowest concentration of $\mathrm{Ca}^{2+}$ in inflow 1 and inflow 2 waters was observed in April (110 and $108 \mathrm{mg}$ $\mathrm{L}^{-1}$, respectively), whereas the highest in September (176 and $167 \mathrm{mg} \mathrm{L}^{-1}$, respectively). A similar trend occurred with reference to $\mathrm{HCO}_{3}{ }^{-}$, whose concentration varied from 302 and $317 \mathrm{mg} \mathrm{L}^{-1}$ in April, respectively, to $465,448 \mathrm{mg}$ $\mathrm{L}^{-1}$ in September. Both $\mathrm{Cl}^{-}$and $\mathrm{SO}_{4}{ }^{2-}$ showed high and multidirectional variability. The highest concentration of chlorides was observed in winter $\left(23.4 \mathrm{mg} \mathrm{L}^{-1}\right.$ in $\mathrm{I} 1$; $19.1 \mathrm{mg} \mathrm{L}^{-1}$ in I2) (Table 1). Biogens showed the highest concentration in winter.

With regard to the Ca concentration, lake waters showed very stable conditions. The lowest values occurred in spring (120 $\mathrm{mg} \mathrm{L}^{-1}$ in April and May) and the highest in summer (131 mg L ${ }^{-1}$ in June). $\mathrm{HCO}_{3}$ concentration showed no seasonal trend, with concentration amounting from 312 to $348 \mathrm{mg} \mathrm{L}^{-1}$. The highest concentration of chlorides, similar to the inlet waters, was observed in winter, i.e., $19.5 \mathrm{mg} \mathrm{L}^{-1}$. $\mathrm{NO}_{3}{ }^{-}$showed the highest concentration in the lake waters among the measured biogens. Generally, biogens showed the highest concentration in winter, but in other seasons, there has not been a clear fluctuation pattern.

Concentration of major ions in water of outflow was less stable than in inflow. $\mathrm{Ca}^{2+}$ concentration amounted from $81 \mathrm{mg} \mathrm{L}^{-1}$ in September to $112 \mathrm{mg} \mathrm{L}^{-1}$ in April, $\mathrm{HCO}_{3}{ }^{-}$ from 213 to $304 \mathrm{mg} \mathrm{L}^{-1}$, respectively. $\mathrm{SO}_{4}{ }^{2-}$ showed both the highest and the lowest concentrations in April 2009 and 2010. The biogen values were the highest in May in the outlet water and the lowest in April, during the meltdown.

Flow rates showed both spatial and temporal variability. The highest values were observed in winter (4.69-118.21 $\mathrm{L} \mathrm{s}^{-1}$ ), while the lowest occurred in summer $\left(0.29-50.86 \mathrm{~L} \mathrm{~s}^{-1}\right)$ in each stream (Table 1). Flow rates presented a pattern: outflow $>$ inflow $2>$ inflow 1 . The same pattern was observed in groundwater recharge. Based on Ferencz and Dawidek's (2014) results and the results confirmed by this study, groundwater supply amounts to circa about $15-20 \%$ of lake input via tributaries. The lake is permanently recharged by the aquifer.

The total range of values of obtained ionic load in almost all cases (except $\mathrm{NH}_{4}{ }^{+}$load) was found to be the greatest in outflow. Quartile range of total phosphorus (TP) and $\mathrm{NH}_{4}{ }^{+}$(except outlet) showed a significant negative skewness (Fig. 3). A close to normal distribution was recorded in case of $\mathrm{NO}_{3}{ }^{-}$in each stream and $\mathrm{PO}_{4}{ }^{3-}$ in inflows. The average values of $\mathrm{NH}_{4}{ }^{+}$and $\mathrm{NO}_{3}{ }^{-}$were an order of magnitude higher than loads of $\mathrm{PO}_{4}{ }^{3-}$ and TP (Fig. 3). The highest dispersion of load values was observed in relation to $\mathrm{NH}_{4}{ }^{+}$in both inflows. A proportion of maximum to minimum values exceeded 220 in $\mathrm{I} 1$ and 
Table 1 Hydrochemical characteristic of Lake Chuteckie, its tributaries, and outflow

\begin{tabular}{|c|c|c|c|c|c|c|c|c|c|c|c|c|}
\hline & \multicolumn{3}{|l|}{ Inflow 1} & \multicolumn{3}{|l|}{ Inflow 2} & \multicolumn{3}{|l|}{ Lake } & \multicolumn{3}{|c|}{ Outflow } \\
\hline & Min & Max & Mean & Min & Max & Mean & Min & Max & Mean & Min & Max & Mean \\
\hline \multicolumn{13}{|c|}{ Concentration $\left(\mathrm{mg} \mathrm{L}^{-1}\right)$} \\
\hline $\mathrm{Ca}^{2+}$ & 107.7 & 176.9 & 128.9 & 108.2 & 166.9 & 128.1 & 120.5 & 130.7 & 124.2 & 112.4 & 136.9 & 122.7 \\
\hline $\mathrm{Mg}^{2+}$ & 0.1 & 3.0 & 1.3 & 0.2 & 8.8 & 3.4 & 0.2 & 4.5 & 2.1 & 0.7 & 26.1 & 7.4 \\
\hline $\mathrm{HCO}_{3}^{-}$ & 283.4 & 465.1 & 356.3 & 310.5 & 419.1 & 341.5 & 312.4 & 356.3 & 333.5 & 307.5 & 236.3 & 334.1 \\
\hline $\mathrm{Cl}^{-}$ & 2.8 & 23.4 & 7.9 & 2.8 & 19.1 & 7.3 & 3.2 & 19.5 & 7.8 & 3.2 & 17.4 & 7.4 \\
\hline $\mathrm{SO}_{4}{ }^{2-}$ & 4.8 & 39.7 & 24.1 & 12.0 & 40.2 & 25.0 & 22.6 & 43.2 & 32.2 & 2.9 & 49.0 & 26.9 \\
\hline $\mathrm{NO}_{3}^{-}$ & 0.1 & 2.8 & 1.5 & 1.1 & 7.0 & 3.0 & 0.0 & 3.5 & 1.6 & 0.4 & 3.4 & 1.7 \\
\hline $\mathrm{PO}_{4}{ }^{3-}$ & 0.001 & 0.2 & 0.1 & 0.0 & 2.2 & 0.4 & 0.008 & 0.4 & 0.1 & 0.02 & 0.4 & 0.1 \\
\hline $\mathrm{TP}$ & 0.01 & 0.5 & 0.2 & 0.006 & 0.4 & 0.1 & 0.006 & 0.4 & 0.1 & 0.01 & 0.3 & 0.1 \\
\hline \multicolumn{13}{|c|}{ Discharge $\left(\mathrm{L} \mathrm{s}^{-1}\right)$} \\
\hline Spring & 2.47 & 72.84 & 24.92 & 3.40 & 118.21 & 116.38 & & & & 6.17 & 116.38 & 43.95 \\
\hline Summer & 0.29 & 28.06 & 4.75 & 0.37 & 43.49 & 50.86 & & & & 0.98 & 50.86 & 10.19 \\
\hline Autumn & 2.45 & 36.35 & 8.14 & 3.38 & 56.35 & 12.12 & & & & 6.14 & 63.03 & 16.61 \\
\hline Winter & 4.69 & 72.84 & 19.58 & 6.67 & 118.21 & 30.56 & & & & 10.77 & 116.38 & 34.19 \\
\hline
\end{tabular}
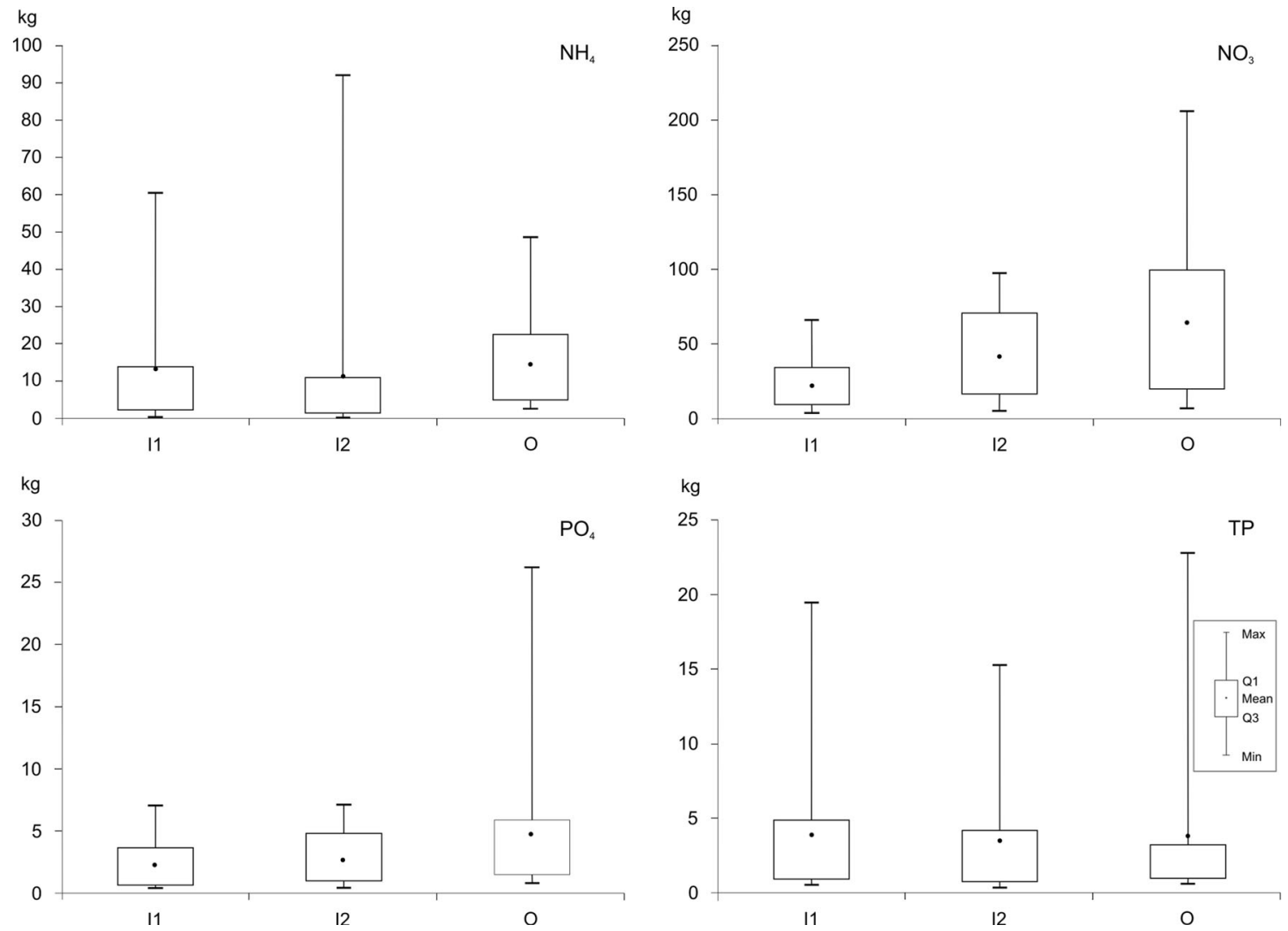

Fig. 3 Values of ionic load carried by inflows and outflow $(\mathrm{kg})$

660 in I2. Multi-annual variability of ionic load on the transect inflow-inflow was observed. Only $\mathrm{NH}_{4}{ }^{+}$for most of the year showed the pattern $\mathrm{I} 1>\mathrm{O}>\mathrm{I} 2$; in case of other ions, changes were fast and multidirectional.

Chemical mass balance of the lake showed great variability. No similarity in the distribution of $\mathrm{NH}_{4}{ }^{+}, \mathrm{NO}_{3}{ }^{-}$, $\mathrm{PO}_{4}{ }^{3-}$, and TP was observed. Values of $\mathrm{NO}_{3}{ }^{-}$mass balance ranged from $-13.5 \mathrm{~kg}$ in October 2010 to $90.6 \mathrm{~kg}$ in 
Table 2 Selected statistical parameters of a chemical mass balance of the Lake Chuteckie $(\mathrm{kg})$

\begin{tabular}{lrrrr}
\hline Key statistics & \multicolumn{1}{c}{$\mathrm{NH}_{4}{ }^{+}$} & \multicolumn{1}{c}{$\mathrm{NO}_{3}{ }^{-}$} & \multicolumn{1}{c}{$\mathrm{PO}_{4}{ }^{3-}$} & \multicolumn{1}{c}{$\mathrm{TP}$} \\
\hline Mean & 9.99 & -0.84 & 0.14 & 3.58 \\
Standard error & 5.18 & 7.73 & 0.84 & 1.42 \\
Median & 3.79 & 7.88 & 0.20 & 1.42 \\
SD & 22.60 & 33.68 & 3.68 & 6.21 \\
Sample variance & 510.69 & 1134.66 & 13.53 & 38.52 \\
Kurtosis & 9.24 & 0.71 & 6.56 & 5.38 \\
Skewness & 2.75 & -1.10 & -1.99 & 2.15 \\
Range & 104.07 & 130.08 & 18.12 & 25.23 \\
\hline
\end{tabular}

April 2009 (Table 2). The mass balance of $\mathrm{NO}_{3}{ }^{-}$showed positive values from the beginning of the observation period to February 2010, as well as in summer 2010. The values amounted from $-83 \mathrm{~kg}$ in April 2010 to $47 \mathrm{~kg}$ in October 2010. The mass balance of $\mathrm{PO}_{4}{ }^{3-}$ showed the lowest variability in the study period (Table 2). The values ranged from $-12 \mathrm{~kg}$ in May 2010 to $6 \mathrm{~kg}$ in June 2009 . Negative values, similar to TP, were observed mostly in summer 2010. Lake's mass balance of TP varied from $-1.6 \mathrm{~kg}$ in May 2010 to $23 \mathrm{~kg}$ in June 2009. In 2009, ionic input was significantly higher in both $\mathrm{PO}_{4}{ }^{3-}$ and TP than in 2010.

RDA analysis was performed to specify direct relationships between chemical and hydrometeorological variables. All chemical variables explained $51.6 \%$ of the total variance. However, variables that significantly explained the variance in water chemistry were precipitation $(\lambda=0.26 ; F=5.96$; $p=0.014)$ and flushing time $(\lambda=0.15 ; \quad F=4.48$; $p=0.030$ ). Generally, inflow (I1, I2) showed significant positive correlation with total phosphorus (TP), $r=0.54$, $p \leq 0.05$ and $r=0.56, p \leq 0.05$, respectively (Fig. 4). Flushing time correlated positively with $\mathrm{PO}_{4}{ }^{3-}(r=0.81$, $p \leq 0.05)$. A mass of major ions: $\mathrm{Cl}^{-}$and $\mathrm{Mg}^{2+}$ were dependent on outlet $r=0.55, p \leq 0.05$ and $r=0.69$, $p \leq 0.05$, respectively. $\mathrm{Ca}^{2+}$ showed a strong negative correlation with precipitation $(r=-0.73, p \leq 0.01)$. RDA allowed to determine the strongest relationships between hydrometeorological parameters and ionic load accumulated in the lake basin. Volatility of allometric relationships in the study period was calculated for: (a) $\mathrm{I} 2$ and TP, (b) $\mathrm{O}$ and $\mathrm{Mg}^{2+}$, (c) $\mathrm{O}$ and $\mathrm{Cl}^{-}$, (d) $\mathrm{Tf}$ and $\mathrm{PO}_{4}{ }^{3-}$, and (e) $\mathrm{P}$ and $\mathrm{Ca}^{2+}$.

For all dependencies, negative allometry was observed in most cases (Table 3). Usually in August (I2 and TP, O and $\mathrm{Mg}^{2+}$, and $\mathrm{Tf}$ and $\mathrm{PO}_{4}{ }^{3-}$ relationships) or in December $\left(\mathrm{O}\right.$ and $\mathrm{Mg}^{2+}, \mathrm{O}$ and $\mathrm{Cl}^{-}$, and $\mathrm{Tf}$ and $\mathrm{PO}_{4}{ }^{3-}, \mathrm{P}$ and $\mathrm{Ca}^{2+}$ relationships), positive allometry occurred for each of the analyzed dependence. It was, however, episodic in nature. Periods of rapid changes of allometric exponents were observed. The more visible was April 2009, when

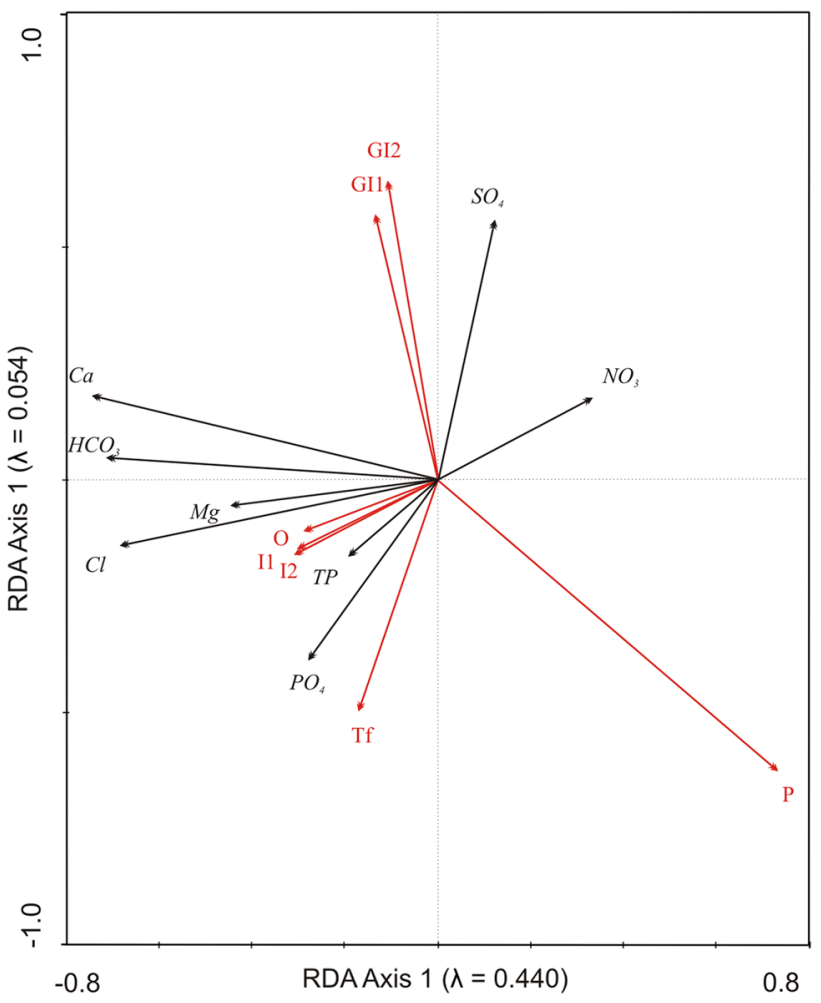

Fig. 4 Redundancy analysis (RDA) biplot showing chemical and hydrometeorological variables

allometric exponent in all case was higher than 1 (positive allometry). Next period of rapid changes occurred in August 2009 (I2 and TP, $\mathrm{O}$ and $\mathrm{Mg}^{2+}$, and $\mathrm{Tf}$ and $\mathrm{PO}_{4}{ }^{3-}$ ), 2010 ( Tf and $\mathrm{PO}_{4}{ }^{3-}$ ), and November or December 2010. The most stable negative allometry conditions were noted in the case of relationship of $\mathrm{I} 2$ and TP, whereas the least stable characterized the relationship of flushing time and $\mathrm{PO}_{4}{ }^{3-}$. Allometric exponents' distribution showed negative skewness. The greatest value of the interquartile range was observed for relations with calcium and precipitation. In this case, the highest mean value 0.58 was also observed.

\section{Discussion}

In terms of Polish lakes, the role of hydrology in water and chemical cycling is poorly elucidated (Klimaszyk and Rzymski 2013). The role of hydrological impulses in shaping water chemistry of lake-catchment systems in terms of Łęczna-Włodawa Lakes is even less known. The results showed that the concentration of measured ions varied seasonally. It has been confirmed in other lakes of the region (Adamczuk et al. 2015a, b). A clear domination of bicarbonate and calcium ions resulted from geological structure of the region and abundance of Cretaceous sediments in the bed rock (Wach 2005; Peczula et al. 2014). 
Table 3 Values of allometric exponents of calculated relationships

\begin{tabular}{|c|c|c|c|c|c|}
\hline & \multicolumn{5}{|c|}{ Allometric relations } \\
\hline & $\mathrm{I} 2$ and TP & $\mathrm{O}$ and $\mathrm{Mg}^{2+}$ & $\mathrm{O}$ and $\mathrm{Cl}^{-}$ & $\mathrm{Tf}$ and $\mathrm{PO}_{4}{ }^{3-}$ & $\mathrm{P}$ and $\mathrm{Mg}^{2+}$ \\
\hline Apr 2009 & 1.00 & 2.00 & 3.00 & 4.00 & 5.00 \\
\hline May 2009 & -0.57 & 6.29 & 0.17 & 0.30 & -0.03 \\
\hline Jun 2009 & 0.01 & 0.02 & 0.02 & -0.03 & -0.02 \\
\hline Jul 2009 & 0.01 & 0.01 & 0.01 & -0.05 & -0.01 \\
\hline Aug 2009 & -1.42 & -5.16 & -0.31 & 1.32 & 0.02 \\
\hline Sep 2009 & -0.02 & 0.10 & -0.12 & 0.44 & 0.41 \\
\hline Oct 2009 & 0.16 & 0.02 & 0.02 & -0.35 & 0.01 \\
\hline Nov 2009 & -0.57 & 0.84 & -0.28 & 2.09 & 0.05 \\
\hline Dec 2009 & 0.02 & -2.68 & 3.92 & 0.64 & -0.03 \\
\hline Jan 2010 & 0.02 & 0.02 & 0.02 & -0.03 & 0.02 \\
\hline Feb 2010 & 0.02 & 0.02 & 0.02 & -0.03 & 0.02 \\
\hline Mar 2010 & -0.42 & 0.22 & -1.00 & -0.02 & -0.02 \\
\hline Apr 2010 & 0.03 & 0.04 & 0.04 & -0.02 & -0.04 \\
\hline May 2010 & 0.19 & 0.10 & 0.10 & -0.01 & 0.10 \\
\hline Jun 2010 & -0.32 & -0.58 & -0.53 & 1.26 & -0.03 \\
\hline Jul 2010 & 0.00 & 0.02 & 0.02 & -0.02 & -0.02 \\
\hline Aug 2010 & 0.13 & -0.81 & -0.62 & 5.00 & 0.29 \\
\hline Sep 2010 & -0.01 & -0.01 & -0.01 & -0.01 & 0.04 \\
\hline Oct 2010 & 0.02 & 0.02 & 0.02 & -0.03 & -2.41 \\
\hline
\end{tabular}

Ferencz and Dawidek (2014) presented the duality of Lake Chuteckie catchment in terms of geological structure. The surrounding vicinity of the lake is formed of organogenic sediments (mostly peat bogs), while the upper catchment parts were made of carbonate rocks. Thus, high runoff and groundwater recharge from Cretaceous aquifer and predominance of carbonate-calcium waters determine good lake water quality compared to other lakes located in Lublin Upland Region: Lake Syczyńskie, Lake Tarnowskie, and Lake Pniówno. The prevalence of hydrological outflow role (higher discharge than in inflowing streams) was observed in other Łęczna-Włodawa lakes by Dawidek and Ferencz (2014). They identified the fact with deepest lakes, where high groundwater recharge is observed. Thermic profile in water column of Lake Chuteckie (data not presented) confirmed high input of groundwater to the lake basin. The results showed significant role of $\mathrm{NH}_{4}{ }^{+}$and $\mathrm{NO}_{3}{ }^{-}$in shaping lake water chemistry. The most stable condition of ionic translocation was observed for $\mathrm{NH}_{4}{ }^{+}$in inflow waters. Values of mass balance of the lake basin showed the dependence from atmospheric precipitation. Positive values of ionic inlets and outlet differences were observed in periods of intensive atmospheric supply and snow meltdown. Negative values were typical for summer, which is typical and results from high primary production and biogen consumption in lake waters (Adamczuk et al. 2015b).
Pęczuła et al. (2014) established ecological state of Chuteckie Lake as high, on the basis of chlorophyll $a$, transparency, conductivity and total phosphorus. It is typically not observed in catchment with prevailing agricultural land use (Jordan et al. 1997; Williams et al. 2005; Smal et al. 2005). Although arable lands amounted to $60 \%$ of the lake catchment, extensive agriculture influenced very little lake water quality. Similar relation was observed by Smal et al. (2005) in Lake Rotcze where, although agricultural lands and meadows and pastures took up $80 \%$ of the catchment, advanced development of submerged macrophytes was observed (Kornijów et al. 2002; Lorens and Sugier 2010). Contrary to the results of Shin et al. (2013), the dissolved ion concentration in Lake Chuteckie catchment was higher in the upper part of the catchment than in the lower part. It indicated the important role of lake basin in ionic retention, which has also been stated by Dawidek et al. (2009) in other small Łęczna-Włodawa Lake (Lake Syczyńskie).

The prevalence of negative allometry indicated the dominance of hydrometeorological factors in shaping water quality of Lake Chuteckie; it results in high stability of geological ions, calcium, and bicarbonate and has been previously observed in other basins located in the southern part of the Łęczna-Włodawa Lakes region (Dawidek 2002). Similar to Lakes Sumin, Rotcze, and Syczyńskie, Lake Chuteckie showed high annual variability of $\mathrm{Mg}^{2+}$ and $\mathrm{Cl}^{2+}$ concentration and significant influence of inlets' 
role in shaping lake water quality (Ferencz et al. 2014). A strong inverse relationship of $\mathrm{Ca}^{2+}$ and precipitation resulted from chemical feature of precipitation, in which Janiec (1999) assessed calcium concentration as $30 \mathrm{mg}$ $\mathrm{L}^{-1}$, as well as the fact that precipitation maxima in the region are observed in summer, when groundwater recharge from Cretaceous sediments is very low. The period when high groundwater inflow is observed is winter, a season of low atmospheric precipitation. A stable and strong relationship of inlet and TP is in line with the results of Smal et al. (2005) for the shallow Łęczna-Włodawa lakes. Allometric relationship of $\mathrm{Tf}$ and $\mathrm{PO}_{4}{ }^{3-}$ pointed to the high role of water exchange in the biogen mass accumulated in the lake waters. Therefore, instability stemmed from the high rate of seasonal variation of $\mathrm{Tf}$ (Ferencz and Dawidek 2014) and high variability of $\mathrm{PO}_{4}{ }^{3-}$. Periods of rapid changes of the values of allometric exponents corresponded with meteorological conditions. After the low quantity of precipitation in February and March 2009, groundwater recharge prevailed in shaping lake water quality (leaching processes). Thus, allometric exponents showed more rapid changes of chemical parameter than in hydrological one. Similar situation occurred in August 2010. Less significant changes of hydrological variables than chemical ones observed in summer resulted from biological processes and biogens accumulation by aquatic organisms (Li et al. 2016).

Open Access This article is distributed under the terms of the Creative Commons Attribution 4.0 International License (http://crea tivecommons.org/licenses/by/4.0/), which permits unrestricted use, distribution, and reproduction in any medium, provided you give appropriate credit to the original author(s) and the source, provide a link to the Creative Commons license, and indicate if changes were made.

\section{References}

Abu-Jaber N (2001) Geochemical evolution and recharge of the shallow aquifers at Tulul al Ashaqif, NE Jordan. Environ Geol 41:372-383

Adamczuk M, Mieczan T, Nawrot D, Rechulicz J (2015a) Indirect effect of environmental factors on interactions between microbial and classical food webs in freshwater ecosystems. Annales de Limnologie-Int J Limnol 51(1):49-58. doi:10.1051/limn/2014032

Adamczuk M, Mieczan T, Tarkowska-Kukuryk M, DemetrakiPaleolog A (2015b) Rotatoria-Cladocera-Copepoda relations in the long-term monitoring of water quality in lakes with trophic variation (E. Poland). Environ Earth Sci 73:8189-8196. doi:10. 1007/s12665-014-3977-z

Apambire WB, Boyle DR, Michel FA (1997) Geochemistry, genesis and health implications of fluoriferous groundwaters in the upper regions of Ghana. Environ Geol 33:13-24

Banoeng-Yakubo B, Yidana SM, Nti E (2009) An evaluation of the genesis and suitability of groundwater for irrigation in the Volta region, Ghana. Environ Geol 57:1005-1010. doi:10.1007/ s00254-008-1385-y
Bull WB (1975) Allometric change of landforms. GSA Bull 86:1489-1498

Cloutier V, Lefebvre R, Therrien R, Savard MM (2008) Multivariate statistical analysis of geochemical data as indicative of the hydrogeochemical evolution of groundwater in a sedimentary rock aquifer system. J Hydrol 353:294-313. doi:10.1016/j. jhydrol.2008.02.015

Coetsiers M, Waltravens K (2006) Chemical characterization of the Neogene Aquifer, Belgium. Hydrogeol J 14:1556-1558. doi:10. 1007/s10040-006-0053-0

Dawidek J (2002) Conditions for formation of chemical composition of Syczyńskie and Tarnowskie lakes. Limnol Rev 2:79-84

Dawidek J, Ferencz B (2014) Water balance of selected floodplain lake basins in the Middle Bug River Valley. Hydrol Earth Syst Sci 18(4):1457-1465. doi:10.5194/hess-18-1457-2014

Dawidek J, Pęczuła W, Ferencz B (2009) The role of catchment and in-lake processes in shaping trophic conditions of the shallow lake Syczyńskie (Eastern Poland). Ecohydrol Hydrobiol 9(2-4):193-200. doi:10.2478/v10104-010-0011-2

Evans IS (2012) Geomorphometry and landform mapping: what is a landform? Geomorphology 137:94-106. doi:10.1016/j.geo morph.2010.09.029

Ferencz B, Dawidek J (2014) The flushing time based on underground supply in the uppermost located Łęczna-Włodawa Lakes. Scott Geogr J 130(4):243-251. doi:10.1080/14702541.2014.890244

Ferencz B, Dawidek J (2015) Allometric relations between fluvial impulse and morphometric parameters of floodplain lakes. Hydrol Process. doi:10.1002/hyp.10618

Ferencz B, Dawidek J, Toporowska M (2014) Hydro-chemical vs. biological conditions of the functioning of three shallow ŁęcznaWłodawa Lakes. Water Environ Res 86(3):269-276. doi:10. 2175/106143013X13807328849332

Hood WG (2007) Landscape allometry and prediction in estuarine ecology: linking landform scaling to ecological patterns and processes. Estuar Coasts 30(5):895-900

Janiec B (1999) Ionic flowage and chemical denudation in Roztocze Region (SE Poland). In: Vlasak P, Filip P, Chara Z (eds) Problems in fluid mechanics and hydrology. Proceedings of the international conference, vol 2. Hydrology and environmental problems. Praque, Czech Republic, pp 483-489

Jordan TE, Correll DL, Weller DE (1997) Relating nutrient discharges from watersheds to land use and streamflow variability. Water Resour Res 33(11):2579-2590

Klein LM, Koelmans A (2011) Quantifying seasonal export and retention of nutrients in West European lowland rivers at catchment scale. Hydrol Process 25:2102-2111. doi:10.1002/ hyp.7964

Klimaszyk P, Rzymski P (2013) Catchment vegetation can trigger lake dystrophy through changes in runoff water quality. Ann Limnol Int J Limnol 49:191-197. doi:10.1051/limn/2013055

Kornijów R, Smal H, Pęczuła W, Lorens B, Rechulicz J, Sugier P, Paleolog-Demetraki A, Tarkowska-Kukuryk M, Ligęza S, Kowalczyk D, Szafran K, Halkiewicz A (2002) Hypertrophication of Lake Syczyńskie (Eastern Poland). Limnol Rev 2:209-215

Lee SW, Hwang SJ, Lee SB, Hwang HS, Sung HC (2009) Landscape ecological approach to the relationships of land use patterns in watersheds to water quality characteristics. Landsc Urban Plan 92:80-89. doi:10.1016/j.landurbplan.2009.02.008

Li QP, Dong Y, Wang Y (2016) Phytoplankton dynamics driven by vertical nutrient fluxes during the spring inter-monsoon period in the northeastern South China Sea. Biogeosciences 13:455-466. doi:10.5194/bg-13-455-2016

Liu WZ, Zhang QF, Liu GH (2011) Effects of watershed land use and lake morphometry on the trophic state of Chinese lakes: 
implications for eutrophication control. CLEAN-Soil, Air, Water 39:35-42. doi:10.1002/clen.20100005

Lorens B, Sugier P (2010) Changes in the spatial structure of submerged macrophytes in Lake Rotcze (Łęczna-Włodawa Lakeland). Oceanol Hydrobiol Stud 39(4):65-73. doi:10.2478/ v10009-010-0049-X

Müller B, Lotter AF, Sturm M, Amman A (1998) Influence of catchment quality and altitude on the water and sediment composition of 68 small lakes in central Europe. Aquat Sci 60:316-337

Pappenberger F, Matgen P, Beven KJ, Henry JB, Pfister L, de Fraipoint P (2006) Influence of uncertain boundary conditions and model structure on flood inundation predictions. Adv Water Resour 29:1430-1449. doi:10.1016/j.advwatres.2005.11.012

Park CC (1978) Allometric analysis and stream channel morphometry. Geogr Anal 10(3):211-228

Pęczuła W, Suchora M, Toporowska M (2014) Ecological and trophic status of two small hardwater lakes of the Lublin Upland with agricultural catchments. Teka (Archives) of the commission of protection and formation of the natural. Environment 11:146-155

Ravinda K, Ameena M, Monika R, Kaushik A (2003) Seasonal variations in physico-chemical characteristics of river Yamuna in Haryana and its ecological best-designated use. J Environ Monit 5:419-426. doi:10.1039/B301723K
Sheffer M (1998) Ecology of shallow lakes. Chapman hall, London

Shin WJ, Ryu JS, Lee KS, Chung GS (2013) Seasonal and spatial variations in water chemistry and nitrate sources in six major Korean rivers. Environ Earth Sci 68:2271-2279. doi:10.1007/ s12665-012-1913-7

Smal H, Kornijów R, Ligęza S (2005) The effect of catchment on water quality and eutrophication risk of five shallow lakes (Polesie Region, Eastern Poland). Pol J Ecol 53(3):313-327

Smidth AR (2002) Analysis of stage-discharge relations for open channel flow and their associated uncertainties. University of Ollinois, Urbana, p 328

Wach T (2005) Changes in the water network in the catchment basin of Lake Zagłębocze (Łęczna-Włodawa Lakeland). Limnol Rev 5:245-254

Wen X, Wu Y, Su J, Zhang Y, Liu F (2005) Hydrochemical characteristics and salinity of groundwater in the Ejina Basin, Northwestern China. Environ Geol 48:665-675. doi:10.1007/ s00254-005-0001-7

Williams AE, Duthie HC, Hecky RE (2005) Water hyacinth in Lake Victoria: why did it vanish so quickly and will it return? Aquat Bot 81:300-314. doi:10.1016/j.aquabot.2005.01.003

Yidana SM, Banoeng-Yakubo B, Sakyi PA (2012) Identifying key processes in the hydrochemistry of a basin through the combined use of factor and regression models. J Earth Syst Sci 121(2):491-507 